\title{
Effect of Pseudotsuga menziesii Plantations on Vascular Plants Diversity in Northwest Patagonia, Argentina
}

\author{
I. A. Orellana and E. Raffaele \\ Additional information is available at the end of the chapter
}

http://dx.doi.org/10.5772/50340

\section{Introduction}

Forests biodiversity conservation is a global concern because they are home to $80 \%$ of the biodiversity of terrestrial environments $[1,2,3,4]$. The replacement of all or part of these ecosystems with monocultures creates mosaics of vegetation, contributing to habitat fragmentation [5]. The new landscape includes more homogeneous vegetation units and may differ in patterns and processes from the original landscape formed by primary or secondary forests.

During the second half of the twentieth century there was an increase of areas subjected to forestations with exotic species. It is estimated that about 187 millions ha were planted worldwide, which represents $5 \%$ of global forests [2]. The annual growth of forest plantations worldwide is estimated at 2-3 million ha per year [6]. Sixty percent $(60 \%)$ of forest plantations are located in four countries: China, India, Russian Federation and United States. In the southern hemisphere, emerging forestry countries are: Brazil, New Zealand, Chile, South Africa, Argentina, Uruguay, Venezuela and Australia [7]. In non-tropical areas, a third of the area of native forest destroyed is used for forest plantations [3].

In the West of Chubut, Río Negro and Neuquén provinces in Argentina, the forested area with exotic species reached 70,000 ha in 2007 [8]. The species used are Pinus ponderosa, Pseudotsuga menziesii, Pinus radiata and Pinus contorta. In the late 1990's it was estimated that forestation had a rates of 10,000 ha per year $[9,10]$. Exotic plantations effects on biological diversity in Austrocedrus chilensis forests and mixed shrublands in Temperate Forests of South America are still poorly understood.

Several studies have shown that species diversity decreases in areas of forestations, and seems to depend on the proximity of plantations to native environments and treatments 
prior to afforest. In Congo, diversity of vascular plants was compared in mixed stands of Eucalyptus - Acacia - Pinus, with secondary forests and the African savannah which showed a reduction in the number of species in plantations understory at compared to the understory of secondary forest. At the plantations edges, however, the loss of species richness was lower, so that proximity to the pre-existing forest help to maintain diversity over short distances [11]. In a conservation rainforest study, the richness of species was found to be lower in Coffea arabica and Elettaria cardamomum plantations than in the native forest [12]. On the other hand, at landscape scale, there has been that E. cardamomum plantations where shrubs and herbs strata were retained, connectivity was maintained among fragmented forest patches. Similar results were found when analyzing the feasibility of employing commercial pine plantations as complementary habitat to conserve threatened species in Chile $[13,14]$.

Besides the proximity to native environments, the diversity in forestations it was found related to age. For example, in 20 years old P. radiata plantations in New Zealand, Rubus fruticosus and other generalist species were frequently found while in later succession (40 years), $R$. fruticosus is replaced by several species of shade-tolerant native ferns and shrubs [15]. Similar results were found in other older plantations of $P$. radiata in New Zealand, where diversity of vascular plants was similar in plantations and nearby native forests, which also was confirmed that plantations provided habitat for some species of birds such as Apteryx mantelli $[16,17]$. In some cases, older plantations increase the supply of habitat, increases in spatial and vertical heterogeneity, increases in light levels, development of organic soil layers and the associated fungal flora [4]. However, there are some studies that show that diversity does not increase with age of forest plantations. The diversity of the beetles ensemble was lower in older plantations of Picea abies than in younger plantations [18].

In Chilean temperate forests, where the replacement of native forests by exotic forestations was important, there was a decrease in the distribution of endangered and vulnerable vascular plants $[19,20]$. There was also a loss of Nothofagus native forest structure, with the disappearance of strata, as well as decreases in species richness of vascular plants [21, 22]. Similar patterns with decreases in vascular plants, beetles and birds species were found in mixed plantations of $P$. menziesii, P. radiata and Pinus sylvestris installed in Nothofagus forests and $P$. ponderosa plantations instaled in the steppe in Argentina [23, 24]. In other studies it was found that the richness and composition of birds was more affected by the structure of plantations than by their tree species composition [25,26]. While a study on ant assemblages showed that in plantations there are decreases in abundance and changes in the composition of species respect to the nearby steppe [27]. All these studies support the hypothesis that high individual density in forest plantations affect biodiversity within them, and propose lower density of trees as an alternative to improve biodiversity.

Diversity loss in South America temperate forests, is a topic of great interest since these ecosystems are characterized by high levels of endemism, a product of a deep biogeographic isolation with common ancestry biota, as well as its extremely heterogeneous floristic composition, derived from various biogeographical sources (e.g. Gondwana, Neotropical, Boreal) $[28,29]$. The vascular flora has about $34 \%$ of woody genera endemic. Most of the 
endemisms are monotypic with only one species per genus [28]. Austrocedrus chilensis is an endemic monotypic species of South America Temperate Forests, with a smaller distribution area than that occupied in ancient geological times [30,31]. At the present, this species has serious conservation problems due to multiple anthropogenic disturbances, and is included in the IUCN Red List in the "vulnerable" status [32]. This chapter presents some results related to vascular plants diversity in A. chilensis forests, and mixed shrublands when they are replaced by the exotic conifer $P$. menziesii plantations.

\subsection{Hypothesis}

In P. menziesii forestations in Patagonia there is reduced vascular plant diversity compared with the natural communities they replace.

\subsection{General aim}

Study and compare the vascular plants diversity in $P$. menziesii forestations and $A$. chilensis forests and mixed shrublands adjacent in the Northwest of Chubut Province and Southwest of the Río Negro Province, Argentina.

\subsection{Specific aims}

1. To estimate the alpha and beta diversity of vascular plants in P. menziesii plantations and contiguous $A$. chilensis forests and mixed shrubland.

2. To analyze the similarity in the composition and abundance of herbaceous and woody shrubs growing in P. menziesii forestations, A. chilensis forests and mixed shrublands.

\section{Methods}

\subsection{Study system}

The study area includes the West of Chubut and the Southwest of the Río Negro Provinces, in Argentina, between the localities of Corcovado $43^{\circ} 32^{\prime} 36.54^{\prime \prime}$ South, $71^{\circ} 26^{\prime} 37.5^{\prime \prime}$ West and

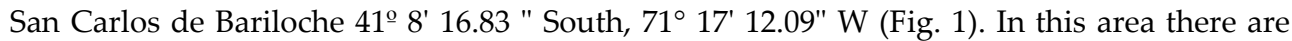
about 103 P. menziesii plantations. The planted surfaces vary between 0.5 and 12 ha, and initial densities are 1.000 trees per ha $[9,33]$. The age of the plantations of P. menziesii studied for 2006, ranged between 17 and 35 years old, and all had reached reproductive maturity. P. menziesii is native to North America where it is distributed between $55^{\circ}$ and $19^{\circ}$ $\mathrm{N}$, in temperate climates [34]. In Patagonia, Argentina, P. menziesii plantations were installed in a range of precipitations between $1500 \mathrm{~mm}$ to $600 \mathrm{~mm}$. In this area, various native plant communities were replaced by afforestations, but the best growths are associated with the natural range of the forests of $A$. chilensis and the mixed shrublands, so that these environments have a higher substitution pressure.

The mixed shrublands are characterized by a shrub stratum of 5 to $7 \mathrm{~m}$ high, in which the most abundant species are: Diostea juncea, Lomatia hirsuta, Embothrium coccineum, Schinus 
patagonicus, Fabiana imbricata and some isolated trees of $A$. chilensis and Maytenus boaria. It is also distinguished is a shrub sub-stratum with similar species composition, and a herbaceous stratum, dominated by species of the families Poaceae, Asteraceae and Rosaceae. In A. chilensis forests a distinguished tree stratum of $15 \mathrm{~m}$ in height is found, in which $A$. chilensis is the dominant species. The shrub stratum was mainly composed by S. patagonicus, L. hirsuta, and E. coccineum, among others. Asteraceae and Poaceae dominate the herbaceous stratum.

\subsection{Sampling design}

Four sites were selected where $P$. menziesii plantations were adjacent to mixed shrublands and eleven sites of $P$. menziesii plantations adjacent to A. chilensis forests (Fig. 1).

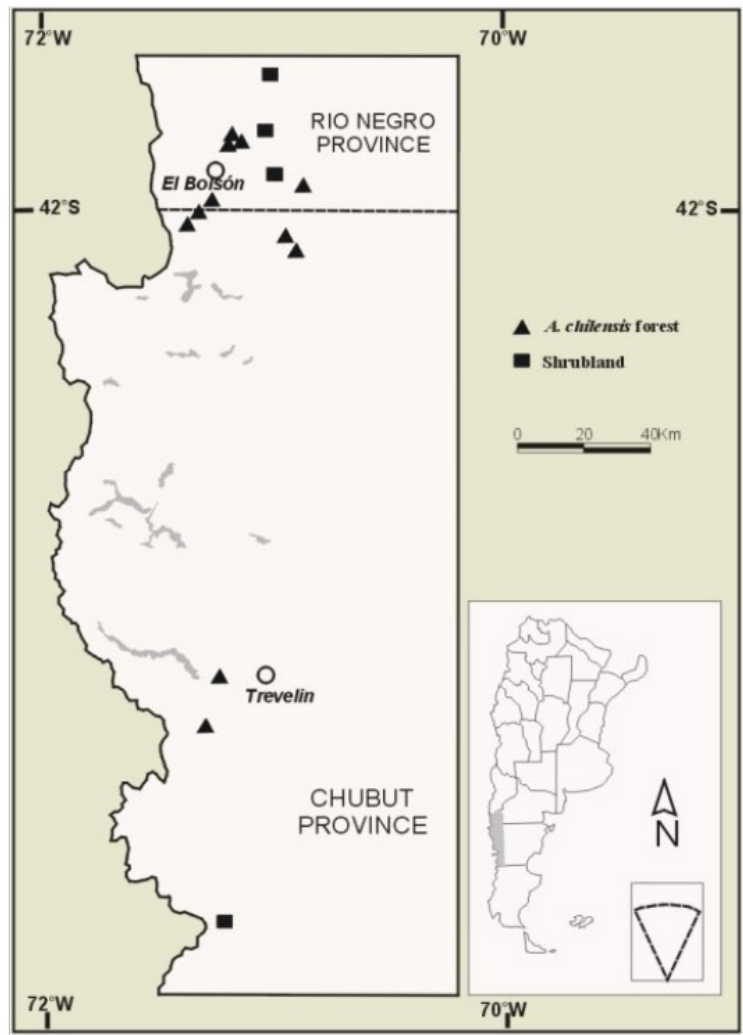

Figure 1. Map of the study area and locations of study sites.

On each site (plantation-native community edge area) a transect perpendicular to the edge line was established (Fig. 2). Each transect was subdivided into 11 plots of $100 \mathrm{~m}^{2}$, three plots were installed in plantations at $-30,-20$ and $-10 \mathrm{~m}$ from the edge line, and eight in the native communities at 10, $20,30,40,50,60,70$ and $80 \mathrm{~m}$ from the edge line. 


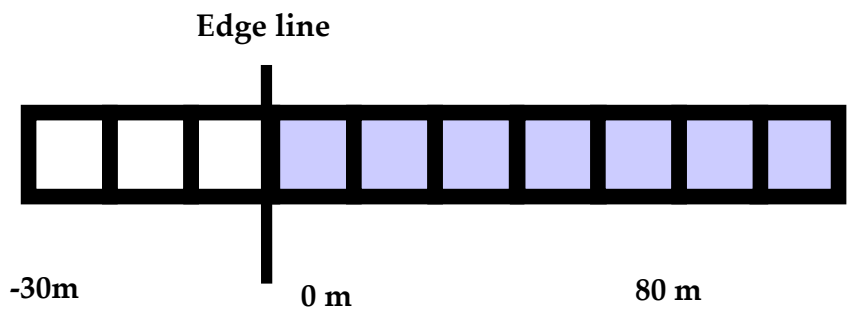

\section{Plantation}

Native community

Figure 2. Scheme of a sampling transect established in a plantation-native community edge area, sampling units (plots) and edge line are indicated.

In each $100 \mathrm{~m}^{2}$ plots, the composition and abundance of vascular plants was registered and mesured, according to the following classification:

1. herbaceous stratum: included herbaceous and woody species seedlings below $10 \mathrm{~cm}$ height. The measurements were performed using four $0.5 \mathrm{~m}^{2}$ circular plots randomly selected within each sampling unit of $100 \mathrm{~m}^{2}$. The species cover percentage was measured, and individual numbers for woody seedlings counted.

2. shrub stratum: included shrubs, woody vines and woody species saplings above $10 \mathrm{~cm}$ in height and below $5 \mathrm{~cm}$ in diameter at breast height (DBH). The number of individuals by species was counted on a plot of $25 \mathrm{~m}^{2}$ randomly selected in each $100 \mathrm{~m}^{2}$ plot.

3. tree stratum: includes trees and shrubs greater than $5 \mathrm{~cm} \mathrm{DBH}$. All individuals were counted in the $100 \mathrm{~m}^{2}$ plot.

Vascular plant field samples were collected and identified in the laboratory. The reference of support was Patagonian Flora collection volume VIII, Parts I, II, III, IVa and b, V, VI and VII [35].

\subsection{Alpha diversity data analysis}

The Alpha diversity analysis was made by species accumulation curves, by using EstimateS software [36, 37]. The vascular plants diversity was analyzed in $P$. menziesii plantations and in the adjacent mixed shrublands, as in plantations and A. chilensis forests contiguous. The Clench equation was used, which has demonstrated good fits for multiple sampling of taxa of species $\left[S_{n}=a^{*} n /\left(1+b^{*} n\right)\right]$, where:

$\mathrm{S}_{\mathrm{n}}=$ mean number species for each sampling unit

$\mathrm{a}=$ increase rate of new species at the beginning of samplings

$\mathrm{b}=$ is a parameter related to the shape of the curve

$\mathrm{n}=$ number of sampling units

This function was applied using a nonlinear estimation, through the iterative adjustment of Simplex and Quasi-Newton algorithm with Statistica $7[38,39]$. The fit of the equation to the accumulation curve, was analyzed by calculating the Determination Ccoefficient: $R^{2}$. The 
slope of the curve (S) when the number of samples is maximum was used to assess sampling quality [S=a / $(1+b n)^{2}$ ] [39]. The flora proportions recorded provided further information on vegetation sampling quality $\left[\left[\mathrm{S}_{\text {obs. }} /(\mathrm{a} / \mathrm{b})\right]^{*} 100\right][39]$.

\subsection{Beta diversity data analysis}

The diversity between habitats was analyzed by using the Jaccard similarity index [37]. This index calculated the species replacement degree across environmental gradients. Where environments are very different, and there are no shared species a 0 value occurs. If all species are shared the index value is set to 1 .

This study the Jaccard similarity index $\left[I_{J}=c / a+b-c\right]$ was obtained for the following pairs of communities: P. menziesii plantations (A)-mixed shrublands (B), P. menziesii plantations (A) - A. chilensis forests (B).

Where:

$\mathrm{a}=$ vascular plant species number in A community

$\mathrm{b}=$ vascular plants species number in B community

$\mathrm{c}=$ vascular plants species number in both $\mathrm{A}$ and $\mathrm{B}$ communities

\subsection{Analysis of similarity in composition and abundance of herbaceous and shrubs species strata by ANOSIM and MDS}

In order to determine if plantations affected the species composition of native communities, the similarity in composition and abundance of herbaceous and shrubs in plantations and native communities were analized by using the multivariate ANOSIM method [40]. This analysis performs permutations on similarity matrices and produces a statistic $(\mathrm{R})$ which is an absolute measure of distance between groups. An $R$ value close to 1 indicates that the assemblages are very different, while a $R$ value close to 0 indicates that the assemblages are similar [40]. To illustrate the assembly of herbaceous and shrub species found in plantations and native communities the Non-Metric Multidimensional Scaling (NMDS) method was applied with the similarity index of Bray-Curtis. These analyzes were performed using the statistical program PRIMER-E Ltd. [41].

\section{Results}

\subsection{Alpha diversity analysis in plantations and native communities}

The species accumulation curves obtained from mixed shrublands and P. menziesii plantations are presented in Figure 3. Both curves show how species richness increases with increasing number of sampling units. They also show that species richness is higher in mixed shrublands that in contiguous $P$. menziesii plantations.

Model (1) describes the species accumulation curve in the mixed shrublands, the model (2) describes species accumulation curve in adjacent $P$. menziesii plantations $(\mathrm{n}=$ number of sampling units). 


$$
\begin{aligned}
& \mathrm{S}_{\mathrm{n} \text { mixed shrublands }}=18,4^{*} \mathrm{n} /(1+0,2 * \mathrm{n}) \quad \mathrm{R}^{2}=0,99 \\
& \mathrm{~S}_{\mathrm{n} \text { P. menziesii plantations }}=3,3^{*} \mathrm{n} /(1+0,22 * \mathrm{n}) \quad \mathrm{R}^{2}=0,99
\end{aligned}
$$

The Determination Coefficients $\left(\mathrm{R}^{2}\right)$ of both models indicate that adjustments to the models accumulation curves are highly representative. Those models were used to calculate the slope of the tangent line when it reaches the maximum number of sampling units. For the species accumulation curve obtained in $P$. menziesii plantations, the slope was $\mathbf{S}=0.25$ ( $\mathrm{n}=$ 12), so it would have been possible to add new species by increasing the sampling units number. The proportion of vascular plants recorded in P. menziesii plantations was $73 \%$. In mixed shrublands, the slope was $\mathbf{S}=0.33(\mathrm{n}=32)$ with a proportion of $86 \%$ of vascular plants recorded.

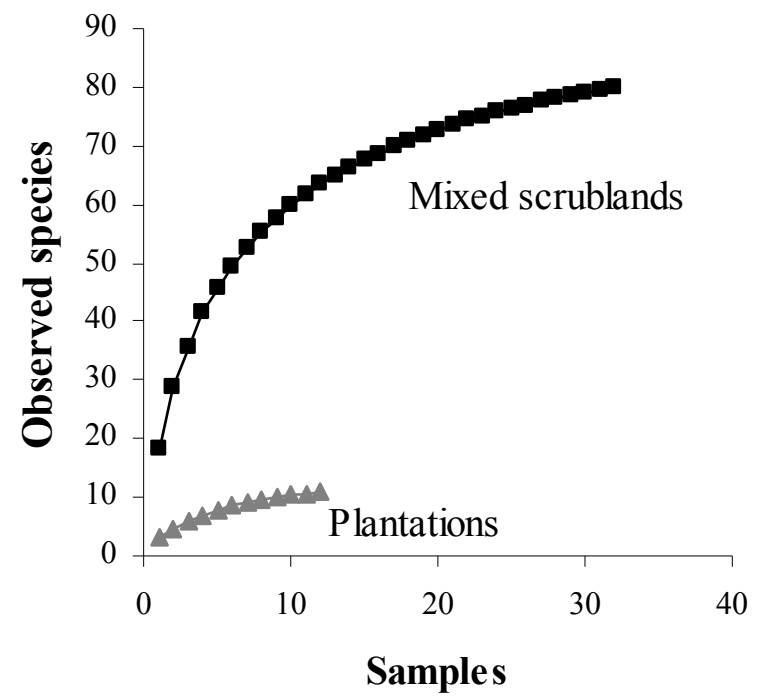

Figure 3. Species accumulation curves obtained from mixed shrublands and the adjacent $P$. menziesii plantations.

The species accumulation curves obtained from A. chilensis forests and P. menziesii plantations also show a greater species richness in $A$. chilensis forests that in $P$. menziesii plantations (Fig. 4).

Model (3) describes the species accumulation curve in A. chilensis forests, model (4) describes the species accumulation curve in adjacent $P$. menziesii plantations $(\mathrm{n}=$ number of sampling units).

$$
\begin{aligned}
& S_{n \text { A. chilensis forests }}=13,05^{*} \mathrm{n} /\left(1+0,07^{*} \mathrm{n}\right) \mathrm{R}^{2}=0,99 \\
& \mathrm{~S}_{\mathrm{n} \text { P. menziesii plantations }}=5,71^{*} \mathrm{n} /\left(1+0,05^{*} \mathrm{n}\right) \mathrm{R}^{2}=0,99
\end{aligned}
$$




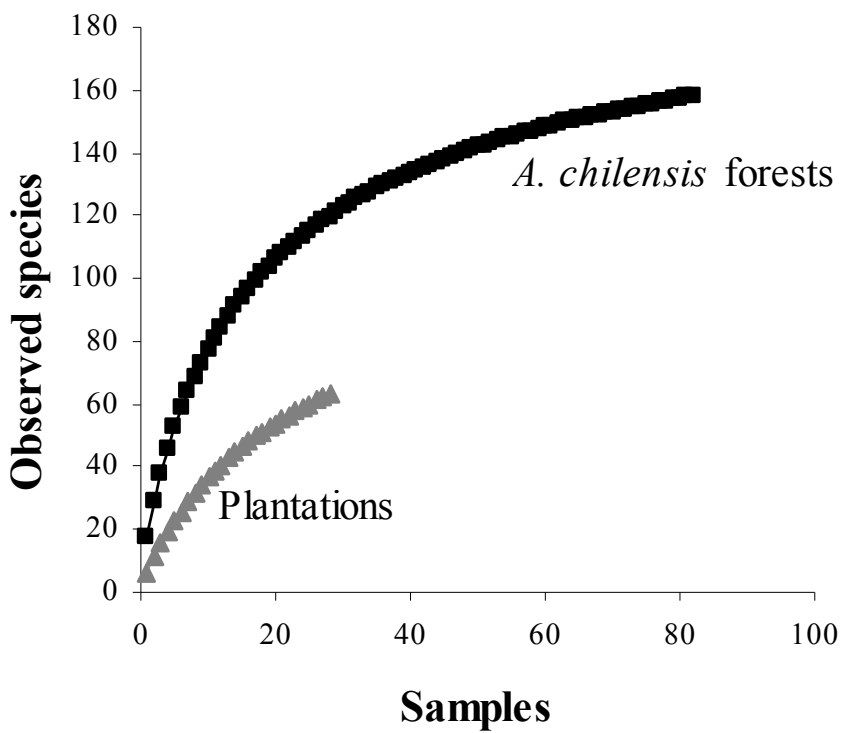

Figure 4. Species accumulation curves obtained from A. chilensis forests and the adjacent $P$. menziesii plantations.

The Determination Coefficients $\left(\mathrm{R}^{2}\right)$ of both models indicate that adjustments to the models accumulation curves are highly representative. For the species accumulation curve obtained in P. menziesii plantations, the slope was $\mathbf{S}=0.88(\mathrm{n}=28)$, so it would have been possible to add new species by increasing the number of sampling units. The sampling registered only $60 \%$ of flora of $P$. menziesii plantations $(\mathrm{n}=28)$. In the A. chilensis forests contiguous afforestations, for $\mathrm{n}=82, \mathrm{~S}=0.28$, so that also have been possible to obtain a greater number of species by increasing the number of sampling units. There, sampling showed $85 \%$ of flora of $A$. chilensis forests.

\subsection{Beta diversity}

When similarity was analyzed between $P$. menziesii plantations and mixed shrublands, the Jaccard index was $0.14 \pm 0.02( \pm \mathrm{SE})$, indicating that plantations and mixed shrublands contiguous are dissimilar in species composition. In the same way P. menziesii plantations and $A$. chilensis forests showed that both adjoining communities were dissimilar in vascular plants composition, the Jaccard index reached a value of $0.17 \pm 0.04( \pm \mathrm{SE})$.

\subsection{Floristic similarity between $P$. menziesii plantations, $A$. chilensis forests and mixed shrublands}

According to the $\mathrm{R}$ value obtained, herbaceous species composition was similar in the three communities studied ( $\mathrm{R}=-0.106, \mathrm{p}=4.3 \%$ ). However, the confidence level for the analysis was not significant $(\mathrm{p}<0.1 \%$ ). The greatest similarities in herbaceous species composition were recorded from $A$. chilensis forests and adjoining plantations, while communities with 
greater differences in herbaceous species composition are plantations and mixed shrublands (Table 1).

$\begin{array}{ccc}\text { Groups } & \mathbf{R} & \text { Significance levels (\%) } \\ \text { F-S } & 0,256 & 95,6 \\ \text { F-P } & -0,02 & 65,4 \\ \text { S-P } & -0,366 & \mathbf{9 9 , 6}\end{array}$

Table 1. Analysis of similarity (ANOSIM) of herbaceous species found in P. menziesii plantations (P), A. chilensis forests (F), and mixed shrublands (S). $R$ value is a measure of similarity of species in different communities, $\mathrm{R}$ values close to 1 indicate differences, and 0 indicate similarities in species composition. Significant values highlighted in bold $(\mathrm{p}<0.1 \%)$.

Non-Metric Multidimensional Scaling (NMDS) analysis, showed greater variability in the composition and abundance of herbaceous species in the differente sites corresponding to $P$. menziesii plantations. Most points (sites) were located towards the periphery of the graph and away from each other (Fig. 5). While in the center of the graph the cloud of points corresponding to mixed shrublands and A. chilensis forest sites. showed a more similar species composition between both native plant communities. Stress $=0.13$, equivalent to a good level of confidence.

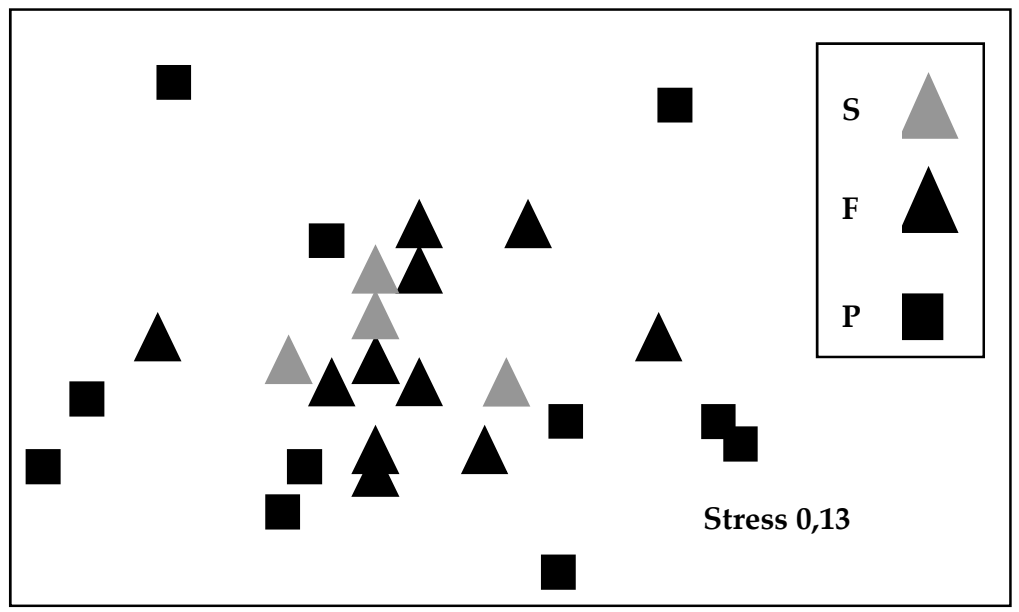

Figure 5. Graphical representation of herbaceous composition and abundance (NMDS) in different communities: $\mathrm{F}=A$. chilensis forests, $\mathrm{P}=P$. menziesii plantations, and $\mathrm{S}=$ mixed shrublands.

Shrub species composition was similar between the communities $(\mathrm{R}=0.2, \mathrm{p}=0.4 \%)$. The more similar communities to each other on shrub species composition were mixed shrublands and $A$. chilensis forests, but as the above analysis, the confidence level was not significant. The least similar communities were forests and plantations (Table 2).

The NMDS analysis shows two clouds of points, one to the right and the other one to the left of the graph (Fig. 6).The right cloud includes points corresponding to P. menziesii 
plantations. This pattern indicates that composition and abundance of shrub species assemblages is more similar between plantations than between plantations and neighboring native communities. To the left, the points cloud is less scattered, includes sites of A. chilensis forests and mixed shrublands. This analysis shows greater similarity in the assembly of vascular plants in $A$. chilensis forests and mixed shrublands.

$\begin{array}{ccc}\text { Groups } & \mathrm{R} & \text { Significance levels (\%) } \\ \text { F-S } & -0,13 & 78,6 \\ \text { F-P } & 0,34 & 0,1 \\ \text { S-P } & 0,20 & 10,2\end{array}$

Table 2. Analysis of similarity (ANOSIM) of shrubs species found in P. menziesii plantations (P), $A$. chilensis forests $(\mathrm{F})$, and mixed shrublands $(\mathrm{S})$. $\mathrm{R}$ value indicates the species similarity between the different communities, $R$ values close to 1 indicate differences, and 0 indicate similarities in species composition.

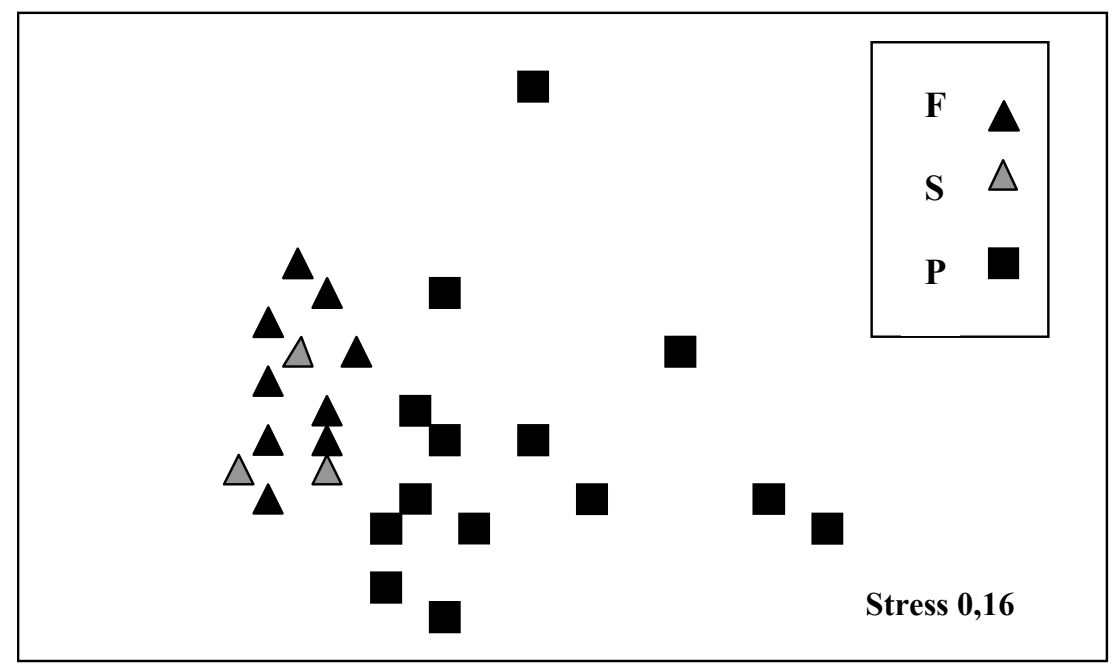

Figure 6. Graphical representation of the ordination (NMDS) of shrub stratum species in different communities: $\mathrm{F}=A$. chilensis forests, $\mathrm{P}=P$. menziesii plantations, and $\mathrm{S}=$ mixed shrublands.

\section{Discussion and conclusions}

In the plant communities studied, the greatest vascular plant diversity was found in A. chilensis forests, where 168 vascular plants species were recorded, while in adjacent $P$. menziesii plantations were $37.5 \%$ of this number of species. In mixed shrublands 86 vascular plants species were recorded, and only $13 \%$ of this species number in contiguous $P$. menziesii plantations. Species accumulation curves allowed comparison of species richness in adjacent communities: $P$. menziesii plantations- $A$. chilensis forests, and $P$. menziesii plantations- mixed shrublands. Greater species richness was observed in native communities than in plantations, confirming that there is a loss of vascular plant diversity in P. menziesii plantations. 
While the similarity analysis (ANOSIM) showed a similar species composition between all pairs of communities, these analyses was not significant. The similarity analysis based on the composition and abundance (NMDS) for herbaceous and shrub strata, showed that both mixed shrublands and $A$. chilensis forests are more similar to each other than with the contiguous $P$. menziesii plantations. It is striking that different native communities (forests and shrublands) separated by distances of up to $400 \mathrm{~km}$ presented the highest similarity of vascular plants. If there was no effect of plantations on vascular plants composition and abundance, a greater similarity between native community and their corresponding neighboring plantation would be expected. In general terms, this analysis confirms that $P$. menziesii plantations changed the native communities with a noticeable loss of diversity and changes in the abundance and composition of vascular plant.

The vascular plants loss in plantations adjacent to mixed shrublands can be explained by decreases in radiation and environmental heterogeneity in plantations [42]. The environmental heterogeneity is an important factor that promotes biodiversity [23, 43]. Differences in radiation between shrublands and plantations, are stronger than differences between $A$. chilensis forests and $P$. menziesii plantations. So understory species of $A$. chilensis forests, could find a more similar environment in adjacent plantations, than species in mixed shrublands [42]. Furthermore, A. chilensis forests are a major source of vascular plants diversity, which may spread to adjoining plantations. While the native communities proximity to plantations promotes species dispersal towards plantations, environmental conditions in plantations prevent the establishment.

The diversity loss found in P. menziesii plantations that replaced A. chilensis forests and mixed shrublands is similar to the results found in Chile, South Africa, New Zealand and Argentina [11, 19-23, 44, 45]. All these studies support the idea that there is a loss of diversity in forest plantations. This study shows the effects on vascular plants diversity when native ecosystems are replaced by exotic species forestations. In addition to changes in vascular plant diversity in forested areas, there are other edge effects that alter vascular plant structure in the native communities surrounding P. menziesii plantations [42]. One of the most important processes recorded in the edge areas is the establishment and dispersion of $P$. menziesii seedlings and saplings from $P$. menziesii plantations [46, 47]. These invasion processes together with diversity loss contribute to native ecosystems degradation.

\section{Author details}

I. A. Orellana

Andean Patagonian Forest Research and Extension Center (CIEFAP), Patagonia San Juan Bosco National University (UNPSJB), Esquel, Chubut, Argentina

E. Raffaele

Ecotone Laboratory, Comahue National University - INIBIOMA/ CONICET,

S. C. de Bariloche, Río Negro, Argentina 


\section{Acknowledgement}

This manuscript was supported by Universidad Nacional de la Patagonia San Juan Bosco PI $N^{\circ}$ 560, Centro de Investigación y Extensión Forestal Andino Patagónico (CIEFAP), and PICTO Forestal №36879 MinCyT Argentina. We would like to thank J. Monges for his field assistance and Javier Puig, Guillermo Defosse and Mark Austin for their help with the language.

\section{References}

[1] Naciones Unidas (1992) Convention on Biological Diversity. New York: Environmental Policy and Law.

[2] FAO (2001) State of the World's forests, 2001. Roma, Italia: Food and Agriculture Organization of the United Nations.

[3] Carnus JM, Parrotta J, Brockerhoff EG, Arbez M, Jactel H, Kremer A Lamb D, O'Hara K, Walters B (2003) Planted Forests and Biodiversit. UNFF Intersessional Experts Meeting on the Role of Planted Forests in Sustainable Forest Management, New Zealand.

[4] Brockerhoff EG, Jactel H, Parrotta JA, Quine CP, Sayer J (2008) Plantation forests and biodiversity: oxymoron or opportunity? Biodiversity Conservation, 17, 925-951.

[5] SchelhasJ, Greenberg R (1996) The value of forest patches. In: J. Schelhas y R. Greenberg (Eds.), Forest patches in tropical landscapes (pp. xv - xxxvi). Washington DC: Island Press.

[6] FAO (2006). Global Forest Resources Assessment 2005-Progress towards sustainable forest management. FAO Forestry Paper 147. Roma, Italia: Food and Agriculture Organization of the United Nations.

[7] Sedjo RA, Lyon KS (1990) The long term adequancy of wordl timber supply. Resource for the future.Washington DC

[8] Rusch V, Vila A (2007) La conservación de la biodiversidad en ambientes bajo uso productivo. I reunión sobre forestación en la Patagonia. Esquel, Argentina: CIEFAP.

[9] Davel M (2008) Estimación de la productividad de sitio. In: M. Davel (Ed.), Establecimiento y manejo del pino oregón en Patagonia (pp. 30-42). Esquel, Argentina: CIEFAP.

[10] Schlichter T, Laclau P (1998) Ecotono estepa-bosque y plantaciones forestales en la Patagonia norte. Ecología Austral, 8, 285-296.

[11] Huttel C, Loumeto JJ (2001) Effect of exotic tree plantations and site management on plant diversity. In: F. Bernhard-Reversat (Ed.), Effect of Exotic Tree Plantations on Plant Diversity and Biological Soil Fertility in the Congo Savanna: With Special Reference to Eucalypts, (pp. 9-18). Bogor, Indonesia: Center for International Forestry Research.

[12] Raman TRS (2006) Efects of habitat structure and adjacent habitats on birds in tropical rainforest fragments and shaded plantations in the Western Ghats, India. Biodiversity Conservation, 15, 1577-1607.

[13] Saavedra B, Simonetti JA (2005) Small mammals of Maulino forest remnants, a vanishing ecosystem of south-central Chile. Mammalia, 69 (3-4), 337-348.

[14] Vergara PM, Simonetti JA (2006) Abundance and movement of understory birds in a maulino forest fragmented by pine plantations. Biodiversity and Conservation, 15 (12), 3937-3947. 
[15] Brockerhoff EG, Ecroyd CE, Leckie AC, Kimberley MO (2003) Diversity and succession of adventive and indigenous vascular understorey plants in Pinus radiata plantation forests in New Zealand. Forest Ecology and Management, 185, 307-326.

[16] Allen .B, Platt KH, Coker REJ (1995) Understorey species composition patterns in a Pinus radiata D. Don plantation on the central North Island volcanic plateau, New Zealand. New Zealand Journal of Forestry Science, 25, 301-317.

[17] Kleinpaste R (1990) Kiwis in a pine forest habitat. In: E. Fuller (Ed.), Kiwis, a Monograph of the Family Apterygidae (pp. 97-138). Auckland, New Zealand: Seto Publishing.

[18] Magura T, Tothmeresz B, Elek Z (2006) Changes in carabid beetle assemblages as Norway spruce plantations age. Community Ecology, 7(1), 1-12.

[19] Benoit I (1989) Libro Rojo de la Flora Terrestre de Chile. Corporación Nacional Forestal, Ministerio de Agricultura, Santiago de Chile

[20] Lara A, Donoso PJ, Cortés M (1991) Development of conservation and management alternatives for native forest in south-central Chile. Santiago, Chile: Reporte Final WWF-US-CODEFF.

[21] Von Buch MW, Osorio M (1987) Probleme um die Pinus radiata-Monokulturen in Südchile. Forstarchiv, 58, 249-253.

[22] Frank D, Finckh M (1997) Impactos de las plantaciones de pino oregón sobre la vegetación y el suelo en la zona centro-sur de Chile. Revista Chilena de Historia Natural, 70, 91-211.

[23] Raffaele, E. y Schlichter, T. (2000). Efectos de las plantaciones de pino ponderosa sobre la heterogeneidad de micrositios en estepas del noroeste patagónico. Ecología Austral, 10, 151-158.

[24] Paritsis J, Aizen MA (2008) Effects of exotic conifer plantations on the biodiversity of understory plants, epigeal beetles and birds in Nothofagus dombeyi forests. Forest Ecology and Management, 255, 1575-1583.

[25] Lantschner MV, Rusch V (2007) Impacto de diferentes disturbios antrópicos sobre las comunidades de aves de bosques y matorrales de Nothofagus antarctica en el NO Patagónico. Ecología Austral 17, 99-112.

[26] Lantschner MV, Rusch V, Peyrou C (2008) Bird Assemblages in Pine Plantations Replacing Native Ecosystems of N.W. Patagonia, Argentina. Biodiversity and Conservation 17(5), 969-989.

[27] Corley JC, Sackmann P, Rusch V, Bettinelli J, Paritsis J (2006) Effects of pine silviculture on the ant assemblages (Hymenoptera: Formicidae) of the Patagonian steppe. Forest Ecology and Management 222, 162-166.

[28] Arroyo MK, Cavieres L, Peñaloza A, Riveros M, Faggi AM (1996) Relaciones fitogeográficas y patrones regionales de riqueza de especies en el bosque templado lluvioso de Sudamérica. In: J. Armesto, C. Villagrán y M.K. Arroyo (Eds.), Ecología de los bosques nativos de Chile (pp. 71-92). Santiago, Chile: Editorial Universitaria.

[29] Armesto JJ, Lobos PL, Arroyo MK (1996) Los bosques templados del sur de Chile y Argentina: Una Isla Biogeográfica. In: J. Armesto, C. Villagrán y M.K. Arroyo (Eds.), Ecología de los bosques nativos de Chile (pp. 23-27). Santiago, Chile: Editorial Universitaria.

[30] Cabrera AL (1971) Fitogeografía Argentina. Boletín de la Sociedad Argentina de Botánica, 14(1), 36-38. 
[31] Donoso C, Escobar B, Pastorino M, Gallo L, Aguayo J (2006) Austrocedrus chilensis (D. Don) Pic. Ser. Et Bizzarri Ciprés de la Cordillera, Len. In: C. Donoso (Ed.), Las especies arbóreas de los bosques templados de Chile y Argentina: Autoecología (pp.54-67). Valdivia, Chile: Mariza Cuneo Ediciones.

[32] IUCN Red List of Threatened Species (2012). Available: www.iucnredlist.org

[33] Gonda H, Mohr Bell D, Sbrancia R, Lencinas J, Bava J, Monte C, Mortero A, Sieber A (2009) Inventario del bosque implantado de la Provincia del Neuquén. Argentina. Patagonia Forestal, 14 (4), 13-16.

[34] Hermann RK, Lavender DP (1990) Pseudotsuga menziesii (Mirb.) Franco. In: R.M. Burns y B.H. Honkala (Eds.) Silvics of Noth America Volume 1 Conifers. Agriculture Handbook 654 (pp. 527-540). Washington, USA: Forest Service.

[35] Correa MN (1971-1999) Flora Patagónica VIII (I, II, III, IVa, IVb, V, VI, VII). Buenos Aires, Argentina: INTA.

[36] Gotelli NJ, Colwell RK (2001) Quantifying biodiversity: procedures and pitfalls in the measurement and comparison of species richness. Ecology Letters, 4, 379-391.

[37] Moreno CE (2001) Métodos para medir la biodiversidad. (Manuales y Tesis 1). Zaragoza, España: Sociedad Entomológica Aragonesa.

[38] Soberón J, Llorente J (1993) The use of species accumulation functions for the prediction of species richness. Conservation Biology, 7, 480-488.

[39] Jiménez Valverde A, Hortal J (2004) Las curvas de acumulación de especies y la necesidad de evaluar la calidad de los inventarios biológicos. Revista Ibérica de Aracnología, 8(31), 151-161.

[40] Clarke KR, Gorley RN (2001) PRIMER V5: User manual tutorial. Plymouth, United Kingdom: Plymouth Marine Laboratory.

[41] Clarke KR (1993) Non-parametric multivariate analyses of changes in community structure. Australian Journal of Ecology, 18, 117-143.

[42] Orellana I (2011) Efecto de borde de las plantaciones de Pseudotsuga menziesii sobre comunidades vegetales naturales en el noroeste patagónico. PhD thesis Universidad Nacional del Comahue, Argentina.

[43] Rosenzweig ML, Abramsky Z (1993) How are diversity and productivity related?. In: R.E. Ricklefs y D. Schuler (Eds.), Species diversity in ecological communities (pp. 52-65). Chicago: University of Chicago Press.

[44] Ogden J, Braggins J, Stretton K, Anderson S (1997) Plant species richness under Pinus radiata stands on the central north island volcanic plateau New Zealand. New Zealand Journal of Ecology, 21(1), 17-29.

[45] Barbaro L, Rossi JP, Vetillard F, Nezan J,Jactel H (2007) The spatial distribution of birds and carabid beetles in pine plantation forests: the role of landscape composition and structure. Journal of Biogeography 34:652-664.

[46] Sarasola MM, Rusch VE, Schlichter TM, Ghersa CM (2006) Invasión de coníferas forestales en áreas de estepa y bosques de ciprés de la cordillera en la Región Andino Patagónica. Ecología Austral, 16(2), 143-156.

[47] Orellana IA, Raffaele E (2010). The spread of Pseudotsuga menziesii in the Austrocedrus chilensis forest and shrubland, in the North Western Patagonia. New Zealand Journal of Forest Science, 40: 199-209. 